\title{
DAMPAK PENGGUNAAN JEJARING SOSIAL TERHADAP KARAKTER SISWA DI SEKOLAH DAARUL FIKRI
}

\author{
Nunung Zaenabiyah \\ IKIP Siliwangi, Cimahi, Jawa Barat, Indonesia \\ nunungzaenabiyyah@gmail.com
}

Received: Desember 2019 ; Accepted: Januari 2020

\begin{abstract}
Globalization Flow is forcing all countries and society in the world to accept the reality of the influx of external influences on various aspects of life. The result of globalization also affects the lifestyle of adolescents. Some young people are more interested in the habits of other countries that are actually not in accordance with the customs and ethics of our nation. The result of globalization on young people is very strong. This influence has made many of our young people lose their personalities as Indonesian Nation, globalization is like a boomerang which if a thrower cannot catch a boomerang that has been thrown properly, it will hurt itself. Social networking is an online network where users can easily interact and give any infomastion to one another but have the negative effect of making users dependent. To avoid using social networks that are not useful and detrimental, it is prioritized the growth of awareness from within yourself in addition to relying on the efforts of various parties such as those closest to you. It is expected that self-awareness will be able to guide users, especially adolescents, to use technology wisely and be able to filter out the good and bad impacts found in the current era of globalization. This research is a quantitative research that aims to find out the result of the use of social networking on student character with data collection instruments in the form of questionnaires, interviews, and documentation and then processed with SPSS v20. Theories that underlies this research include the theory of character education, social networking theory, and the theory of non-school education. The results proved that the internet social network proved to have an effect on the character of the Daarul Fikri School students. The importance of the role of parents and teachers to be able to guide students in schools so that they are wise in using social networking is very necessary, because in addition to having a large positive impact, social networking also has a large negative impact as well.
\end{abstract}

Keyword: Social Networking, Character Education

\begin{abstract}
ABSTRAK
Arus globalisasi memaksa seluruh negara dan lapisan masyarakat di dunia untuk menerima kenyataan masuknya pengaruh luar terhadap berbagai aspek kehidupan. Dampak dari globalisasi juga dapat mempengaruhi gaya hidup para remaja. Sebagai generasi masa kini yang lebih tertarik dengan adat negeri lain yang kenyataan nya tidak sesuai dengan adat istiadat dan kebiasaan bangsa kita. Pengaruh globalisasi terhadap anak muda saat ini begitu kuat. Saat ini anak muda kita kehilangan kepribadian diri sebagai bangsa Indonesia akibat pengaruh tersebut, globalisasi saat ini seperti boomerang yang jika pelempar tidak dapat menangkap boomerang yang telah dilempar dengan baik maka dapat melukai diri sendiri. Jejaring sosial adalah sebuah jejaring online yang para penggunanya dapat dengan mudah berinteraksi dan berbagi informasi satu sama lain tetapi memiliki efek negatif menjadikan ketergantungan para penggunanya. Untuk meminimalisir pengguna jejaring sosial dari hal-hal yang tidak baik dan merugikan, diharapkan kesadaran diri sendiri akan mampu menuntun pengguna situs tersebut dengan baik, khususnya anak dan remaja untuk dapat
\end{abstract}


menggunakan teknologi dengan bijak dan dapat menyaring informasi yang baik maupun yang buruk yang terdapat pada era globalisasi saat ini. Penelitian ini menggunakan penelitian kuantitatif yang bertujuan untuk mengetahui pengaruh penggunaan jejaring sosial terhadap karakter siswa dengan instrument pengumpulan data berupa kuesioner, interview, dan dokumentasi kemudian diolah dengan SPSS v20. Teori yang menjadi rujukan pada penelitian ini diantaranya teori pendidikan karakter, teori jejaring sosial, dan teori pendidikan luar sekolah. Hasil temuan membuktikan bahwa jejaring sosial internet terbukti berpengaruh bagi karakter siswa siswi Sekolah Daarul Fikri. Pentingnya peranan dari orang tua dan guru untuk bisa membimbing siswa di sekolah agar bijak dalam menggunakan jejaring sosial yang saat ini sangat diperlukan, karena selain memiliki dampak positif yang besar, jejaring sosial juga mempunyai dampak negatif yang besar pula.

Kata Kunci: Jejaring Sosial, Pendidikan Karakter

How to Cite: Zaenabiyah, N. (2020). Dampak Penggunaan Jejaring Sosial Terhadap Karakter Siswa Di Sekolah Daarul Fikri. Comm-Edu (Community Education Journal) 3 (1), 68-74.

\section{PENDAHULUAN}

Di era globalisasi saat ini memaksa seluruh negara dan lapisan masyarakat di dunia untuk menerima kenyataan dengan masuknya pengaruh luar terhadap berbagai aspek kehidupan. Kemunculan internet merupakan salah satu perkembangan masuknya era globalisasi dan dengan adanya sosial media yang membuat masyarakat didunia dapat terkoneksi satu sama lain dalam lingkungan global yang tanpa batas. Kemajuan teknologi ini memberikan dampak positif dari segi kemudahan masyarakat untuk memperoleh pengetahuan dan informasi (Hernynda Maghfira, Kompasiana 2016).

Dalam bahasa inggris situs jejaring sosial disebut social network sites adalah sebuah website berbasiskan pelayanan yang memungkinkan penggunanya untuk membuat biografi, mengamati daftar pengguna yang ada, dan mengajak atau menerima teman pada situs tersebut untuk bergabung. Bentuk dari situs jejaring sosial ini menghadirkan laman biografi pengguna, yang didalamnya terdapat identitas diri dan juga foto pengguna. Situs jejaring sosial adalah situs utnuk membantu seseorang membuat sebuah biografi dan dapat menyambungkan dengan pengguna lain. Situs jejaring sosial adalah aplikasi yang memungkinkan penggun untuk terhubung menggunakan profil pribadi atau akun pribadinya. Adapun contoh berbagai situs jejaring sosial seperti Facebook, Instagram, Twitter, juga termasuk Whatsapp. (Juditha, 2011).

Berdasarkan hasil Polling Indonesia yang berkolaborasi dengan Asosiasi Penyelenggara Jasa Internet Indonesia (APJII), di Indonesia total pengguna internet meningkat 10,12\%. Menurut Sekjen APJII, Henri Kasyfi, peninjauan ini menyertakan 5.900 sampel dengan margin of error 1,28 persen. Menurut henri, dari jumlah populasi sebanyak 264 juta jiwa penduduk di Indonesia, terdapat sebanyak 171,17 juta jiwa atau kurang lebih 64,8 persen yang telah tersambung ke internet. Angka ini mengalami peningkatan dari tahun 2017 ketika angka ini penetrasi internet di Indonesia tertulis sebanyak 54,86 persen. Henri mengatakan "Dari tahun ke tahun angka kita terus naik". Menurut Henri, sumbangan terbesar di Indonesia untuk penetrasi internet bermula dari pulau jawa. Di pulai jawa ini angka penetrasi meraih $55 \%$ dari jumlah keseluruhan. Sementara di Pulau Sumatera berada di posisi kedua dengan data penetrasi sebesar 21\%. Pulau Jawa, Provinsi Jawa Barat menjadi wilayah dengan angka pengguna internet terbesar hingga mencapai $16 \%$ dari seluruh pengguna internet di Indonesia. Mayoritas yang diketahui dapat mengakses dunia maya yaitu masyarakat dengan rentang usia 
15 hingga 19 tahun. Dengan demikian, Henri pun mengungkapkan bahwa konten-konten yang beredar di Internet harus lebih diawasi. Untuk umur, paling banyak di usia 15 sampai 19 tahun. Makanya konten-konten harus semakin diperhatikan," ungkap Henri (Yudha Pratomo, Tekno.Kompas.com 2019).

Pada dasarnya, jejaring sosial ini sangat berpengaruh kepada user disebabkan oleh intensitas penggunaannya. Menurut Nurkholif Hazim (2005), bahwa: "intensitas adalah kebulatan tenaga yang dikerahkan untuk suatu usaha". Intensitas adalah kenyataan dari motivasi untuk mencapai tujuan yang diinginkan yaitu meningkatkan prestasi, karena dengan melakukan usaha penuh semangat seseorang akan termotivasi sebagai dorongan mencapai prestasi.

Berdiskusi mengenai penguatan pendidikan karakter terutama kepada siswa-siswi dalam situasi sekarang sangat berkaitan untuk memberantas kriris moral yang sedang terjadi di sekolah-sekolah. Dipercaya atau tidak saat ini sedang terjadi krisis moral yang faktanya sangat menghawatirkan lingkungan sekolah yang melibatkan siswa. Contoh krisis itu sendiri berupa meningkatnya pergaulan seks bebas, maraknya angka-angka kekerasan anak-anak dan remaja dan banyak lagi contoh lainnya.

Menurut Al-Ghazali sebuah perilaku terjadi karena peran junud atau Al-qolbi (tentara hati). Dalam diri manusia terdapat dua junad alqolb, yaitu yang bersifat fisik berupa anggota tubuh yang berperan sebagai alat, dan yang bersifat psikis, yang bersifat psikis yang berwujud dalam dua hal yaitu syahwat dan ghodob (Al-Ghazali, 2000).

Syeikh al-Zarnuji, penulis kitab Ta'lim al-Muta'allim Thariq al-Ta'allum (Syeikh al-Zarnuji, 2009), menekankan aspek nilai adab, baik adab batiniyah maupun adab lahiriyah, dalam pembelajaran. Kitab ini mengajarkan bahwa, pendidikan bukan sekedar transfer ilmu pengetahuan dan ketrampilan (skill), namun paling penting adalah transfer nilai adab. Kitab yang populer di pesantren-pesantren yang ada di Indonesia ini menjelaskan tentang konsep pendidikan Islam secara utuh, tidak dikotomis. Seharusnya bahwa, karakter itu sejatinya karakter beradab, yang artinya seimbang antara adab batiniyah dan adab lahiriyah.

Adapun nilai-nilai karakter yang perlu di tanamkan kepada peserta didik menurut Heritage Foundation dan tertuang dalam sembilan pilar karakter yang dicetuskan oleh Ratna Megawangi adalah (Dharma Kesuma, dkk, 2011)

Dituangkan juga Dalam Peraturan Presiden Nomor 87 Tahun 2017 tentang penguatan Pendidikan Pendidikan Karakter terdapat nilai-nilai yang perlu diterapkan untuk menguatkan pendidikan karakter. Terdapat 18 nilai pada peraturan presiden tersebut, antara lain: Religius, Jujur, Toleransi, Disiplin, Kerja Keras, Kreatif, Mandiri, Demokratis, Rasa Ingin Tahu, Semangat Kebangsaan, Cinta Tanah Air, Menghargai Prestasi, Bersahabat/Komunikatif, Cinta Damai, Gemar Membaca, Peduli Lingkungan, Peduli Sosial, Tanggungjawab.

Tujuan penelitian ini untuk mengetahui pengaruh jejaring sosial internet terhadap karakter siswa siswi di Sekolah Daarul Fikri dan untuk mengetahui jejaring sosial internet apa yang paling banyak digunakan oleh siswa siswi di Sekolah Daarul Fikri.

Berdasarkan latar belakang yang telah diuraikan di atas maka permasalahan yang diangkat dalam penelitian ini yaitu : apakah jejaring sosial internet berpengaruh bagi karakter siswa di Sekolah Daarul Fikri?. 


\section{LANDASAN TEORI \\ Jejaring Sosial}

Jejaring Sosial merupakan situs dimana seseorang dapat membuat web page pribadi dan terhubung dengan setiap orang yang tergabung dalam jejaring sosial yang sama untuk berbagi informasi dan berkomunikasi (Zubaedi, 2013).

\section{Pendidikan Karakter}

Pendidikan karakter dalam Peraturan Presiden Nomor 87 Tahun 2017 adalah pendidikan yang menumbuhkembangkan nilai-nilai karakter luhur kepada peserta didik, sehingga mereka memiliki karakter luhur itu, menerapkan dan mempraktikkan dalam kehidupan keluarga, sebagai anggota masyarakat dan warga negara.

\section{METODOLOGI PENELITIAN}

Penelitian ini merupakan penelitian kuantitatif yang bertujuan untuk mengetahui pengaruh penggunaan jejaring sosial terhadap karakter siswa dengan 3 tahapan penelitian yaitu tahap persiapan (survey awal ke lapangan), tahap pelaksanaan (terjun ke lapangan dengan instrument penelitian) dan tahap evaluasi (merapikan data sebelum diolah).

Teknik pengambilan sampel dalam penelitian ini secara khusus dengan proportionate stratified random sampling. Proportionate stratified random sampling adalah pengambilan sampel dari anggota populasi secara acak dan berstrata secara proporsional, dilakukan sampling ini apabila anggota populasinya heterogen (tidak sejenis). Proportionate stratified random sampling ini dilakukan dengan cara membuat lapisan-lapisan (strata), kemudian dari setiap lapisan diambil sejumlah subjek secara acak. Jumlah subjek dari setiap lapisan (strata) adalah sampel penelitian (Sugiyono, 2009).

Penelitian ini memiliki 3 instrumen kuesioner untuk mengukur pengaruh penggunaan jejaring sosial terhadap karakter siswa, wawancara untuk mendapatkan informasi langsung di lapangan dari bebrapa orang yang dianggap relevan dengan pokok pembahasan, ini dilakukan untuk mendapatkan data yang valid, dan dokumentasi untuk mendapatkan data tentang dokumen-dokumen yang ada, dengan melalui sumber-sumber yang berkaitan dengan kajian yang dibahas.

Hasil kuesioner, wawancara, dan dokumentasi kemudian Seluruh data dalam penelitian ini diolah dengan menggunakan IBM SPSS Statistika version 20 dan Microsoft excel 2019 untuk mengetahui seberapa besar pengaruh jejaring sosial terhadap karakter siswa (studi kasus kepada siswa-siswi Sekolah Daarul Fikri).

Subjek dalam penelitian ini adalah siswa-siswi tingkat sekolah dasar dan sekolah menengah pertama yang berjumlah 160 orang. Dari 160 populasi maka dipilih atau ditarik sampel dengan menggunakan teknik proportionate stratified random sampling, sebanyak $50 \%$ x 160 $=80$ sampel.

\section{HASIL DAN PEMBAHASAN}

\section{Hasil}

Berdasarkan pengolahan data yang telah dilakukan diperoleh hasil sebagai beikut: 
72 Zaenabiyah, N, Damak Penggunaan Jejaring Sosial Terhadap Karakter Siswa di Sekolah Daarul Fikri

Tabel 1. Jejaring sosial

\begin{tabular}{|c|c|c|c|c|}
\hline Batas Kategorisasi & Interval & Frek. & Per. & Ket. \\
\hline$(24+1.0(5)) \mathrm{x} \leq$ & $29 \leq \mathrm{x}$ & 13 & $16,25 \%$ & Tinggi \\
\hline$(24-1.0(5)) \leq \mathrm{x}<(22+1.0(5))$ & $19 \leq \mathrm{x}<29$ & 57 & $71,25 \%$ & Sedang \\
\hline $\mathrm{x}<(24-1.0(5))$ & $\mathrm{x}<19$ & 10 & $12,5 \%$ & Rendah \\
\hline \multicolumn{2}{|c|}{ Total } & 80 & $100 \%$ & \\
\hline
\end{tabular}

Berdasarkan tabel 1 kategori dari hasil analisis data diatas, bisa dilihat bahwa ada 13 siswa yang memakai jejaring sosial yang masuk pada kategori tinggi dengan perolehan nilai persentase sebesar 16,25\%, sedangkan 57 siswa masuk pada kategori sedang dengan jumlah nilai persentase sebesar $71,25 \%$, dan 10 siswa lainnya masuk pada kategori rendah dengan nilai persentase sebesar $12,5 \%$.

\section{Jejaring Sosial}

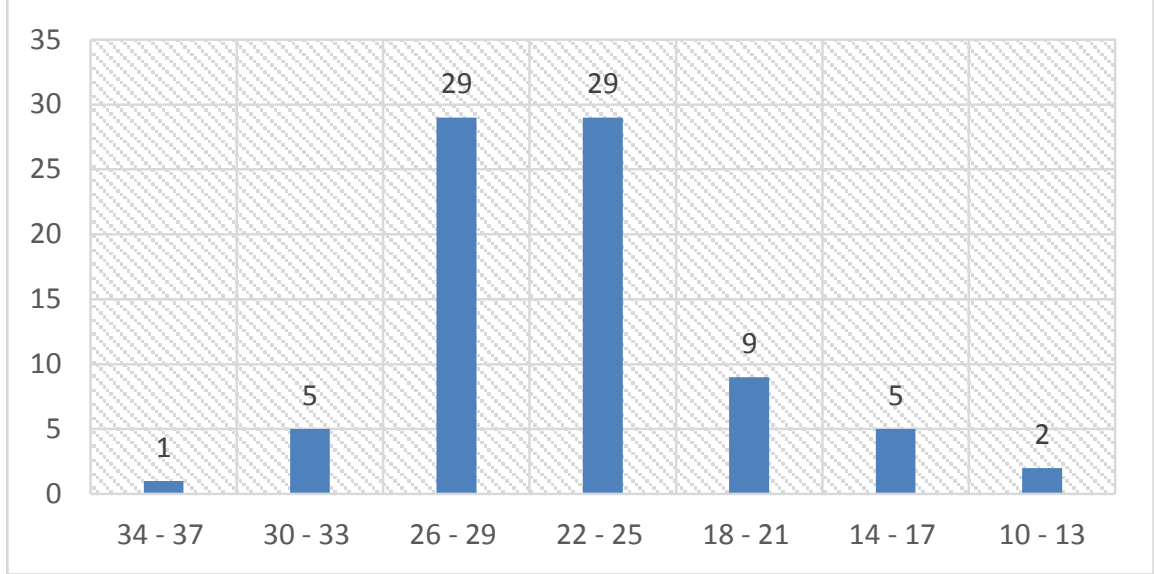

Gambar 1. Penggunaan Jejaring Sosial

Tabel 2. Karakter Siswa

\begin{tabular}{|c|c|c|c|c|}
\hline Batas Kategorisasi & Interval & Frek. & Per. & Ket. \\
\hline$(22+1.0(4)) \mathrm{x} \leq$ & $26 \leq \mathrm{x}$ & 16 & $20 \%$ & Tinggi \\
\hline$(22-1.0(4)) \leq \mathrm{x}<(22+1.0(4))$ & $18 \leq \mathrm{x}<26$ & 49 & $61,25 \%$ & Sedang \\
\hline $\mathrm{x}<(22-1.0(4))$ & $\mathrm{x}<18$ & 15 & $18,75 \%$ & Rendah \\
\hline \multicolumn{2}{|r|}{ Total } & 80 & $100 \%$ & \\
\hline
\end{tabular}

Pada tabel kategori hasil analisis data diatas, bisa dilihat bahwa ada 16 siswa yang berkarakter masuk pada kategori tinggi dengan nilai persentase sebesar 20\%, sedangkan 49 siswa masuk pada kategori sedang dengan nilai persentase sebesar $61,25 \%$, dan 15 siswa lainnya masuk pada kategori rendah dengan nilai persentase sebesar 18,75\%. 


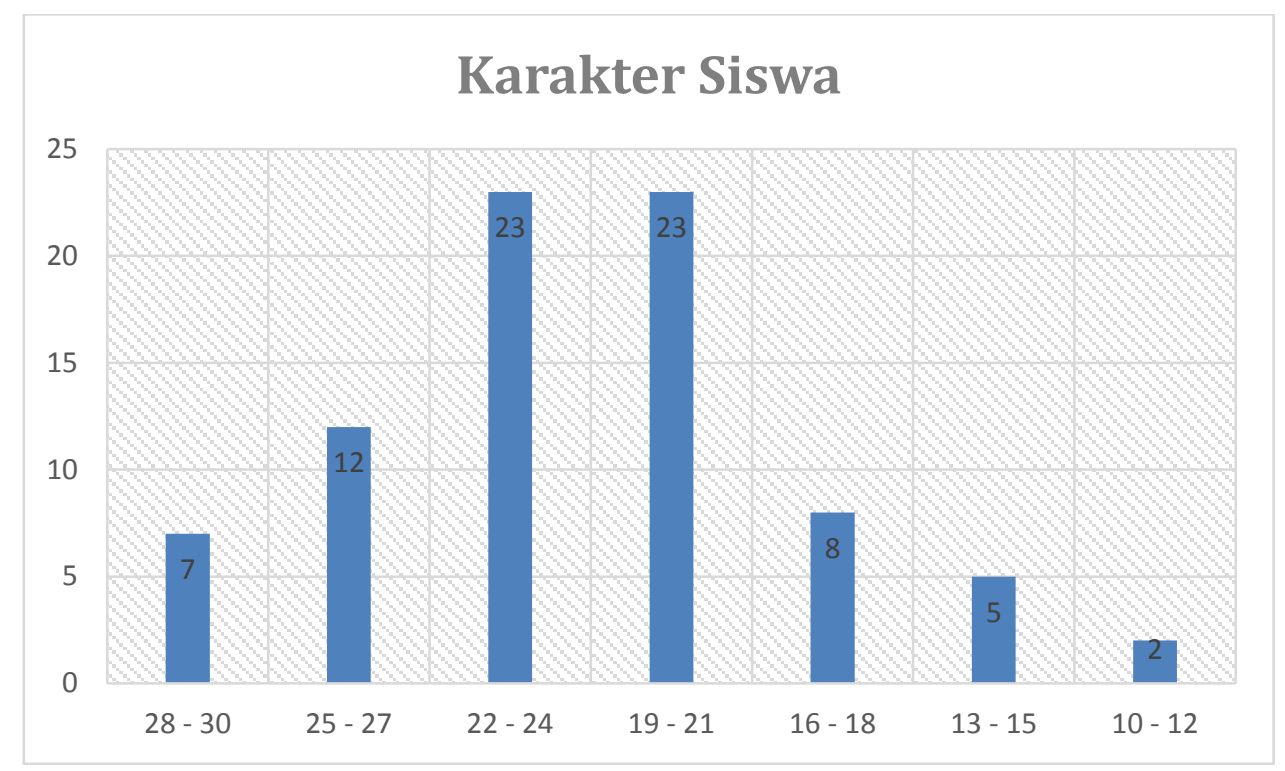

Gambar 2. Karakter Siswa

Setelah dilakukan uji signifikansi melalui uji t, diperoleh persamaan:

$$
\mathrm{t}=\frac{r \sqrt{n-2}}{\sqrt{1-r^{2}}}=\frac{0,418 \sqrt{80-2}}{\sqrt{1-0,418^{2}}}=4,473
$$

Tabel t dengan $\alpha 0,1 t_{\text {tabel }} ;=1,664<t_{\text {hitung }}=4,473$

Maka Ho diterima, sehingga kesimpulannya adalah terdapat pengaruh yang signifikan antara jejaring sosial terhadap karakter siswa siswi di Sekolah Daarul Fikri.

\section{Pembahasan}

Jejaring sosial merupakan situs dimana seseorang dapat membuat web page pribadi dan terhubung dengan setiap orang yang tergabung dalam jejaring sosial yang sama untuk berbagi informasi dan berkomunikasi (Zubaedi, 2013). Dengan menggunakan jejaring sosial siswa seharusnya dapat memperoleh banyak pengalaman belajar tentang bagaimana caranya bersosialisasi dan memanajemen hubungan tersebut dengan cara memanfaatkan jejaring sosial di era digital seperti saat ini.

Adanya jejaring sosial siswa dapat belajar dengan cara mengembangkan keahlian teknis dan sosial yang dibutuhkan siswa dalam menghadapi era digital. Siswa berkomunikasi dengan kerabatnya melalui jejaring sosial, dan dapat memanajemen pertemanannya. Dengan adanya jejaring sosial siswa akan meningkatkan jejaring pertemanannya tanpa harus bertemu langsung dan akan lebih mudah menghasilkan suatu komunitas yang bermanfaat untuk mereka, baik dalam diskusi pelajaran ataupun hal-hal yang memberi kontibusi positif bagi mereka. Dengan adanya komunitas pertemanan yang semakin luas, dapat memotivasi siswa untuk menegembangkan diri baik dari segi materi ataupun masukan dari teman-teman baru mereka yang tersambung secara online.

Namun ada juga dampak jejaring sosial yang malah bersifat negatif terhadap siswa. Diantaranya siswa menjadi kecanduan sehingga lebih asik bermain gadget dibanding belajar, terbukti banyak juga yang lupa waktu, bahkan mereka terlalu sering membuat postingan status berupa tulisan maupun foto dan kondisi mentalnya sangat terpengaruh oleh respon orang lain terhadap postingan tersebut. Perubahan pada individu sangat dipengaruhi dari 
74 Zaenabiyah, N, Damak Penggunaan Jejaring Sosial Terhadap Karakter Siswa di Sekolah Daarul Fikri

aktivitas yang dilakukan dan tergantung pada pilihan dari individu tersebut dalam berperilaku (Fibrianto dan Bakhri, 2018).

Kingsley Davis (dalam Soekanto, 2009: 262) mengemukakan bahwa perubahan sosial merupakan bagian dari perubahan kebudayaan. Perubahan dalam kebudayaan mencakup semua bagiannya, yaitu kesenian, ilmu pengetahuan, teknologi, filsafat, dan seterusnya, bahkan perubahan-perubahan dalam bentuk serta aturan-aturan organisasi sosial. Siswa yang menggunakan sosial media internet akan meningkatkan interaksi sosialnya. Tetapi juga memiliki efek negatif yaitu menurunkan prestasi akademiknya (Al-Rahmi WM, 2013)

\section{KESIMPULAN}

Jejaring sosial sangat berpengaruh terhadap karakter siswa, dimana siswa dapat menambah jaringan pertemanannya di dunia maya tanpa harus bertemu langsung dan dapat memudahkan mereka menciptakan suatu komunitas yang bermanfaat bagi mereka, entah itu komunitas dalam diskusi mata pelajaran ataupun hal lainnya yang dapat memberikan kontribusi positif kepada mereka. Walaupun tidak bisa dipungkiri terdapat efek negatif berupa kecanduan jejaring sosial, lebih asik bermain gadget, lupa waktu, lebih suka sendirian, kurang sosialisasi, dll jika dalam perjalanannya siswa tidak dibimbing dengan baik tentang cara memanfaatkan jejaring sosial ini dengan bijak.

\section{DAFTAR PUSTAKA}

Al-Ghazali. (2000). Mengobati penyakit hati terjemah Ihya' Ulum Ad-Din, dalam Tahdzib AlAkhlaq wa Mu" alajat Amradh Al-Qulub. Bandung: Karisma.

Al-Rahmi WM. (2013). The Impact of Sosial Media Use on Academic Performance among University Student: A Pilot Study. Johor, Malaysia. Journal of Information System Research and Innovation.

Al-Zarnuji, Syeikh. (2013). Ta'lim al-Muta'allim Thariq al-Ta'allum. Surabaya: Mutiara Ilmu Surabaya.

Fibrianto, A. S., \& Bakhri, S. (2018). Pelaksanaan Aktivitas Ekstrakurikuler Paskibra (Pasukan Pengibar Bendera) dalam Pembentukkan Karakter, Moral dan Sikap Nasionalisme Siswa SMA Negeri 3 Surakarta. Jurnal Moral Kemasyarakatan.

Juditha, Christiany. (2011). Pengaruh Penggunaan Situs Jejaring Sosial Facebook Terhadap Perilaku Remaja di Kota Makassar. Journal [Online]. Vol 13 no.01.

Kesuma, Dharma dkk. (2011). Pendidikan Karakter: Kajian Teori dan Praktik di Sekolah. Bandung: Remaja Rosdakarya.

Maghfira, Hernynda. (2016). Sosial Media di Era Globalisasi, Baik atau Buruk?. Kompasiana. Diakses dari https://www.kompasiana.com/

Nurkholif. (2005). Intensitas Belajar. Jakarta: Remaja Rosdakarya.

Peraturan Presiden Nomor 87 Tahun 2017 tentang penguatan Pendidikan Karakter.

Pratomo, Yudha. (2019). APJII: Jumlah Pengguna Internet di Indonesia Tembus 171 Juta Jiwa. Tekno Kompas. Diakses dari https://tekno.kompas.com

Soekanto, S. (2009). Sosiologi Suatu Pengantar. Jakarta: PT. Rajagrafindo Persada.

Sugiyono. (2009). Metode Penelitian Administratif. Bandung: Alfabeta.

Zubaedi. (2013). Desain Pendidikan Karakter. Jakarta: Kencana Prenada Media Group. 